\title{
Borghini's Dilemma
}

\author{
Print Thinking and the Digital
}

\author{
Presidential Address 2019
}

H. Wayne Storey

\begin{abstract}
The sixteenth-century Florentine philologist Vincenzo Borghini provides a model for our own examination of the influence of print as we consider the challenges, opportunities and responsibilities of producing digital editions and archives. Briefly examining several emended passages in the 1573 expurgated edition of Boccaccio's Decameron, the essay turns to Borghini's reliance in his 1574 Annotationi on his extensive studies of fourteenth-century Italian vernacular in manuscripts and their contrasts with the printed editions of his own day often edited - he fears - simply to sell books. Turning from Borghini's skepticism to his own editorial work for the 2003-2004 facsimile and commentary, the author reflects upon the failures of his own edition for the print medium and how they led to the founding and development of the Petrarchive's rich-text edition and commentary. Reflecting on two examples of the representation of the use of space in Petrarch's medieval holograph possible only in a born-digital edition, the essay concludes its brief demonstration of the deep structuring of print in philological thinking as we develop new strategies for digital philology.
\end{abstract}

For

ThOSE OF YOU UNFAMILIAR WITH THE WORK OR EVEN THE name of the Renaissance Florentine philologist Vincenzo Borghini (15151580), I must apologize for the rare reference in my title. ${ }^{1}$ Borghini is not a household name, not even in Italy. ${ }^{2}$ A learned Benedictine monk,

1. The original essay from which this presidential address was drawn examines how the deep structures of print function at the core of the critical edition's philological apparatus. That essay, far too long for an after-dinner address, will be published separately. In keeping with the tradition of publishing the presidential address in Textual Cultures, I have elected instead to maintain for the most part the presentation's original structure and tone. Some elucidations have been added both in notes and in the text.

2. For a general introduction to the philological work of Vincenzo Borghini, see Belloni and Drusi 2002, an exemplary primer in the assessment of the deep 
Borghini is remembered for his interest in manuscripts and his philological prowess, but is also renowned for an editorial failure, that is for his role in the 1573 expurgated edition of Boccaccio's Decameron, as well as for a remarkable volume of annotations and discussion of the textual condition of the work carried out by Borghini and his fellow commissioners, the "Deputati". ${ }^{3}$ Though the 1573 edition saw but one printing, his 1574 Annotationi, devoted to explanations of the process of amending the edition and a study of Boccaccio's language were reprinted until 1857 (see FANFANI 1857), the relevance of Borghini's sixteenth-century research into the manuscripts and contexts of the Decameron was still deemed relevant by nineteenth-century philology.

After the Council of Trent, whose decrees were first published in 1564, Borghini and his fellow commissioners were given the task by the Church in Rome of producing a learned edition from an expurgated text that rewrote or selectively censored (usually with asterisks) those tales in Boccaccio's famous work that offended the Church or lessened the moral stature of priests and nuns. ${ }^{4}$ If the edition's solutions led to some scholarly dereliction, they also supplied us — thanks to Borghini — with an erudite restoration of Boccaccio's fourteenth-century Italian. The edition also gave us remarkably inventive narrative changes: Boccaccio's original convent of nuns ("un monistero di donne" [BRANCA 1992, III 1, 1]) producing many little monks ("assai monachin" [III 1, 42]) fathered by a fellow whom the nuns believed was a gardener bereft of the power of speech becomes the castle of a widowed countess who takes in poor young women ("una Cont-

and strict methodological relationship between Borghini and the manuscripts he studied. The volume traces Borghini's extraordinarily learned interests and studies in art, antiquities and literature through many of his own manuscripts and those he used and annotated.

3. Originally published in quarto (specifically $235 \times 160 \mathrm{~mm}$ [text-block $180 \times 100 \mathrm{~mm}]$ ), Borghini's 1574 Annotationi was often bound as an appendix, with its title page, fascicles and pagination intact, to Borghini's 1573 edition of the Decameron, with the "Annotationi", along with their indices, privileges and final device (and "Registro"), now appearing before Borghini's introduction to the work ("Proemio", signatures $\mathrm{Aa} \mathrm{Bb} \mathrm{Cc} \mathrm{Dd,} \mathrm{the} \mathrm{last} \mathrm{of} \mathrm{which} \mathrm{includes}$ Filippo and Iacopo Giunti's address to the readers). The text-block of the 1574 Annotationi $(180 \times 100 \mathrm{~mm})$ varied only slightly from that of the 1573 Decameron $(175 \times 100 \mathrm{~mm})$.

4. Ratified in early 1564 by Pius IV's papal bull, Benedictus Deus, the decrees were first published same year in Rome by Aldo Manutius's son Paolo (Aldo dies in 1515) as Canones et decreta sacrosancti oecumenici et generalis Concilii Tridentini. 
essa [. . .] rimasa vedova haveva una usanza di ritenere appresso di se alcune damigelle povere" [Borghini 1573, 141]) who sleep with the gardener; the sexually liberated monk of Day 1 , Tale 4 who tricks his abbot into the same carnal sin in which he has engaged ("un monaco caduto in peccato [. . .] rimproverando al suo abate quella medesima colpa, si libera dalla pena" [BRANCA 1992, I 4, 1) becomes a student who escapes punishment for his pleasure by getting his teacher to fall for a woman who appears in his cell ("Uno scolare caduto in peccato [. . . ] rimproverando al suo maestro quella medesima colpa, si libera dalla pena" [Borghini 1573, 31]). ${ }^{5}$ Only the infamously licentious story of Rustico, the anchorite (Decameron III 10) who teaches the very devout Alibech "true devotion", escapes Borghini's revisionist narrative skills with much of its text reduced to an asterisk that stands in for some of the most explicit sexual descriptions in the Decameron. The loss of key portions of the text replaced by strategic asterisks to substitute long sections of text renders the story dull and virtually incomprehensible. ${ }^{6}$ The initial description of the story, a kind of abstract supplied by Boccaccio for all the tales, itself pivots on a crude but popular phrase to describe sexual intercourse: "Alibech divien romita, a cui Rustico monaco insegna rimettere il diavolo in Inferno: poi, quindi tolta, diventa moglie di Neerbale" [Branca III 10, 1]). But Borghini has little ideological choice; philology and explicit innuendo have gone by the wayside: "Alibech diviene romita * poi quindi tolta diventa moglie di Neherbale" $(1573,197)$. Gone are the devil and hell and mention of the anchorite Rustico. Just a few lines later, Alibech only has a chance to meet the holy man Rustico before a great fire in her hometown of Gafsa, in Tunisia, kills most of her family, leaving the fourteen-year-old Alibech heir to her family's fortune and forcing her to return home and marry the enterprising Neerbale. Only a trace of Rustico's trials after his quick capitulation to temptation remains after a single asterisk substitutes just over $63 \%$ of the tale between Alibech's initial meeting with Rustico and her return to Gafsa, eliminating completely their long exchanges about devotion/sex: "il cui nome era Rustico, et quella dimanda gli fece, che a gli altri haveva fatta. * Hora avvenne che

5. References to Branca's critical edition follow the editor's divisions of the Day in which the tale occurs, the sequential number of the story within the Day and the paragraph, while references to Borghini's 1573 edition note simply the page number. My transcriptions from sixteenth-century editions distinguish between $u$ and $v$ and change the long-s to a short-s. No punctuation has been altered or added. Abbreviations have been expanded in italics.

6. Of course today the asterisks would be used to signal a corrupt or irresolutely contaminated reading. 
un fuoco s'apprese in Capsa [. . .]" (Borghini 1573, 198 [BrancA 1992, III $10,9 * 31]) .^{7}$ In Borghini's edition all that remains is what is now Rustico's inexplicable happiness over Alibech's departure for Gafsa when he has just met her: "con gran piacer di Rustico, et contra al volere di lei [Neerbale] la rimenò in Capsa" (Borghini 1573, 198). ${ }^{8}$ Also gone is one of medieval Italy's most delightful parodies of the temptations of the desert anchorites celebrated by Boccaccio's contemporaries as absolute examples of religious devotion beyond the devil's most intense temptations. ${ }^{9}$

It bears pointing out that Borghini was not, to put it bluntly, an ideological hack. His philological work on the Decameron and other works he knew well, including Dante's Commedia and Giovanni Villani's Chronicle of Florence (Nuova cronica 1344-1348), was based upon a profound knowledge of their manuscript traditions. Facing the task of editing one of the icons of early Italian prose, Borghini would have remembered well the good old days when even fellow monks and religious, such as the Benedictine Niccolò (Nicolaus) and an alternating unknown hand had in 1396 transcribed word for word without a whiff of censorship one of the early copies of the Decameron (today MS Firenze, Biblioteca Nazionale Centrale, Banco Rari 37). And Borghini must surely have known of the complete 1483 edition of the Decameron printed by the Florentine sisters at their press at the convent in San Jacopo di Ripoli. ${ }^{10}$

Borghini's 1573 Decameron was quickly and roundly criticized. Perhaps anticipating such attacks from literati and presses, the edition's subtitle contained virtually a legal disclaimer of its history: the text, by the Florentine citizen Giovanni Boccaccio, had - first of all - been newly corrected (Ricorretto) and emended (Emendato) in Rome by order of the Sacred Council of Trent; and — secondly — the text was produced in Florence by a process of comparing the work's ancient copies (Testi Antichi) and edited (ridotto) by the Commissioners into its "true form" (vera lezione):

7. The translation reiterates the narrative desolation of the expurgated edition's version: "whose name was Rustico; and she asked him the same questions she had asked the others. * Then it happened that a fire occurred in Gafsa".

8. Borghini's expurgated tale here reads: "to Rustico's great pleasure, and against her will [Neerbale] led her back to Gafsa".

9. For a prolonged study of the rhetorical structures at the heart of Boccaccio's satire, see Storey 1982.

10. For further discussion of MS Banco Rari 37, see Cursi 2007, 74-6; for the early copy of the Decameron printed by the Dominican sisters at San Jacopo di Ripoli on the press of the goldsmith and typographer Bernardo Cennini, see Conway $1999,43 n 136$. 
Il Decameron di Messer Giovanni Boccacci. Cittadino Fiorentino. Ricorretto in Roma, et Emendato secondo l'ordine del Sacro Concilio di Trento, Et riscontrato in Firenze con Testi Antichi \& alla sua vera lezione ridotto da' Deputati da loro Alt[ezze] Ser[enissime]

Borghini 1573, 1 (title page)

From the Annotationi alone it would be impossible to discern the reasons for the 1573 edition's most dramatic narrative reinventions and alterations, but Borghini reacts to the results. Calling the edition a "ritoccamento" and "il presente racconciamento" (sign. Aa1) at the beginning of his long address (Proemio) to his readers (A' Benigni, Eु Discreti LETTORI, [sign. Aa1-Dd4]), he ultimately mourns the reduced state of Boccaccio's masterpiece after its sanitizing and then the work of piecing it back together in an acceptable form:

Ma perche il libro restava in alcuni luoghi talmente tronco \& cosi male appiccato il filo del ragionamento insieme, che difficile era cavarne senso, \& quasi impossibile poterlo leggere: ne fu da loro dato alcuno ordine di potere rappiccare insieme queste membra sparte: accioche la narratione del fatto venisse (quando la cosa pativa) continuata. ${ }^{11}$

The edition represents a problematic mixture of repression and philology, a contradictory fusion of linguistic and textual research and linguistic/ thematic suppression, the former more fully addressed in Borghini's 1574 Annotationi et discorsi sopra alcuni luoghi del Decameron . . . Sopra la corretione di esso Boccaccio, stampato l'Anno MDLXXIII, published by the same Giunti. Borghini found himself caught between two ideologies: religious and textual. And while his philological discomfort with Rome's ordered suppression of parts of Boccaccio's work is borne out even in the title, in page after page of his Annotationi, it becomes ever more evident that the Florentine philologist suffers another dilemma as well. Though he has prepared a text for publication in a technology that had already been in use for a hundred years, the very notion of the textual authority and supe-

11. Borghini 1574, sign. Aa2r. "But since the book remained in some passages so chopped up and the narrative thread barely held together, so much so that it was difficult to make sense of it and virtually impossible to read, the [Church's] official request was to find a way to piece back together what remained of these narratives so that where it suffered the text would again be part of a sensical narrative thread". 
riority unfolds in a nuanced intellectual struggle between the admirable but printed 1527 Florentine Decameron, cited throughout the Annotationi, and his preferred "Testi Antichi" represented primarily by the handwritten exemplar of 1384 (today MS Firenze Biblioteca Laurenziana 42.1), signed by Francesco d'Amaretto Mannelli and referred to by Borghini, and subsequently through the centuries, as "l'ottimo esemplare" (the best exemplar). ${ }^{12}$ For Borghini, it is Boccaccio's "originale" that served as Mannelli's antegraph. ${ }^{13}$ Borghini's attention to the manuscript's details includes Mannelli's marginal annotations, upon which Borghini often stops to reason and discuss the reading in the manuscript, its copyist and the edition's solution. Justifying a reading still adopted by modern editors for Decameron III 765 ("di lui temendo, come de morti corpi, se poi veduti andar come vivi, si teme"), Borghini notably mines not only Mannelli's manuscript but also draws upon the linguistic usage of the early Tuscan Trecento writers found in the manuscripts he has studied. His entry for III 7 reasons through Mannelli's text, his exemplar, his marginalia and even the fourteenth-century copyist's "reverence for the text". The passage is worth examining in its initial constructions:

La parola Fossero non era nell'Originale, il che ci significò il Mann[elli] che non l'ha, \& scrive in margine. sic erat textus. La qual Chiosa puo esser segno, che e' dubitasse di mancamento, ma per riverentia del testo non ardisse toccare. Et cosi sarebbe questo un ristrignersi nelle spalle \& dire che se difetto ci è non viene da lui. Potrebbe ancora pel contrario significare, che e' ne fusse sicurissimo, \& da vantagio volesse assicurare noi con questa nota, quasi che e' dicesse. Non ci dubitare d'errore alcuno, perche cosi ha il testo dello Autore. Noi volentieri inchiniamo a questa seconda, perche piu di una volta si troverranno cosi fatti difetti (se difetti si debbono chiamare, \& non piu presto figure e gratiose licentie delle

12. In the early 1570 s we are still four centuries before the discovery and confirmation of Boccaccio's own late (1370) holograph copy of Decameron in what is today MS Berlin Staatsbibliothek Hamilton 90, nonetheless problematic for its missing fascicles, which have been unscientifically substituted by relevant sections of Mannelli's "ottimo manoscritto" (MS Laurenziano 42.1).

13. For example, see Borghini 1574, sign. H2v-3r ("come havea l'originale [. . .]"). While paginated, the 1574 Annotationi suffered from significant errors in its page numbers in its $\mathrm{G}$ and $\mathrm{H}$ signatures. To reduce this confusion I cite only the signatures and their chartae. 
lingue) in questo \& altri buoni Scrittori nostri \& Romani, Et ce n'è un mondo di esempi. ${ }^{14}$

Borghini's deep dive into Mannelli's manuscript and the possible thinking of its copyist is not an exercise in a collation for variants but the demonstration of Borghini's method of absorbing the forma mentis of manuscript culture that transmits the linguistic and syntactic trends of early Italian literature that are not to be gleaned from printed editions. Deemed "defects" by Borghini's contemporary editors interested in "modernizing" and standardizing the language and in selling books, according to Borghini they are instead the remnants of the authentic forms that graced the literary origins - Latin and Italian - that inform Boccaccio's "original".

In the pages of his Annotationi, Borghini dutifully recognizes the "noble and learned young" scholars who with "gran diligentia \& non minor giuditio" corrected the text of the Decameron for the 1527 edition (1574, sign. $\mathrm{Bb} 2 \mathrm{v})$. On the very next page $(\mathrm{Bb} 3 \mathrm{r})$, Borghini even says that there are not large differences between the 1527 Florentine edition and the Ottimo manuscript of 1384. These are the pages, however, where Borghini begins his lessons on Boccaccio's language that the Florentine monk has studied in the context of the manuscripts of Boccaccio's fourteenth century, materials with which the 1527 editors of the printed Florentine edition were unfamiliar. The subtlety of Borghini's constant referral to these manuscripts, and especially to the 1384 "Ottimo" exemplar of the Decameron, is summarized and - with far less nuance - clarified by Filippo and Iacopo Giunti, the publishers of the 1573 edition and the 1574 Annotationi, characterizing the printed tradition of Boccaccio's Decameron as "corrupt and beyond repair [. . . ] perhaps in order to make printers' books more sellable

14. Borghini 1574, sign. H2v. "The word Fossero was not in the Original, which meant that Mannelli doesn't put it in his copy but writes in the margin: thus was the text. This Gloss can be a sign that Mannelli had his doubts that a word was missing, but out of reverence for the text he didn't dare touch the passage. This would be a kind of shrugging of his shoulders and an admission that if there is a defect it doesn't come from him [Mannelli]. It could also mean the opposite: that he was certain of the reading of his copy and that he could easily reassure us with this [marginal] note, as if to say: Don't worry that there might be an error here since this is exactly how the Author's text reads. We gladly bow to this second reason since more than once these so-called defects (if we can even call them 'defects' and not the figures and charming license of languages) can be found in this work as well as in other good Italian and Roman Authors; and there are a lot of examples". 
to the common herd" ("molto corrotta, e guasta, forse per rendere i libri loro piu vendibili al vulgo" [1574, sign. *2v]). Instead, Borghini and his colleagues have worked directly from numerous handwritten witnesses, foremost among them being Mannelli's excellent copy:

[. . . ] hora è stato fatto stampare da noi dintorno alla correzione del testo, leggere si deue, e non altramente, essendosi detti Deputati serviti dell'ottimo esemplare del Mannelli, del quale in piu luoghi si fa menzione, con la testimonanza di molti altri anchora confrontato, si come essi nel Proemio delle dette Annotazioni diffusamente di tutto rendono chiara, e giustificata ragione. ${ }^{15}$

But page after page of his Annotationi bear out Borghini's reliance on and preference for the medieval manuscripts in which he has absorbed the authentic linguistic forms of Boccaccio's literary predecessors and contemporaries. Reading through Borghini's studies in the Annotationi we reflect more and more on his description of what we come to realize is the bad deal that Borghini and his fellow Deputati agreed to take on and, even more evident across the pages of the Annotationi is fact that the Renaissance philologist's true dilemma has to do with the nature of print itself. For Borghini print, and printers' wholesale corruption of texts for profit and for a much wider circulation of moral corruption, has ushered in the suppressive intervention of Rome and the Council of Trent. In this light, our Borghini has been charged with the task of producing in print a philologically accurate text that by doctrinal necessity betrays the philological rigor of the best witness, Mannelli's 1384 handwritten copy.

Borghini was not the first to grapple with the overly standardizing and reductive norms of printing on texts that had enjoyed the graphological freedom of handwriting. Vespasiano da Bisticci, the paper merchant turned purveyor of manuscripts for the libraries of the rich and famous, gave up his lucrative trade of deluxe manuscripts around 1480 when printing presses continued to meet with ever greater approval and commercial success (though many failed quickly). Individual works such as the Divine Comedy and Petrarch's Canzoniere (more appropriately known by Petrarch's title

15. "[. . . ] now we have had printed the correction of the text, which must be read simply because the Commissioners used Mannelli's superb exemplar, often mentioned in our commentary, as well as many other witnesses with which we compared it, all of which the Preface to the noted Annotations makes abundantly clear and justified". 
Rerum vulgarium fragmenta [Rvf]) had found already in the fourteenth-and early fifteenth-century's distinctive mises en page that were quickly altered in the earliest editions of both works (respectively 1472 [Foligno: Johannes Numeister] and 1470 [Venice: Wendelin of Speier]) to facilitate typesetting and space for handwritten marginalia or illustration. If there was one lesson from these editiones principes, it was that print would force a re-envisioning of the works themselves. This was certainly the case when the Paduan printer Bartolomeo Valdezoco had a look at Petrarch's supervised and partially holograph manuscript of the Rvf for his 1472 edition. ${ }^{16}$ His colophon tells us that his volume is "taken from [Petrarch's] original book" ("ex originali libro extracta"), a claim to authenticity that had been repeated in numerous fourteenth- and fifteenth-century manuscripts, but in Valdezoco's case the claim was accurate. But with Petrarch's authorized manuscript under his nose Valdezoco's typographical guide was not Petrarch's mise en page for sonnets and the other four genres that constitute the Fragmenta but early fifteenth-century manuscripts such as British Library Kings 321 (dated 1400), Cornell Library MS 4648n22A (ca. 1470), and Beinecke Library M706 (ca. 1465-1470). ${ }^{17}$ Since we know his editor worked in Padova directly from Petrarch's own manuscript with its unique and authorized mise en page, Valdezoco's verifiable conversion for his 1472 printed edition codifies two essential characteristics of Petrarchan poetics in late fifteenth-century print culture: the visual isolation of the single verse and the primacy of the complete sonnet, and — when possible — the single page containing two complete sonnets, which for the print tradition of the Rvf would become a typographical standard that endured into the twentieth century in editions without commentary. To maintain that primacy, where necessary, Valdezoco adjusts the editorial blank space to conclude where possible each page with a complete sonnet. In Figure 1 we see how with the conclusion of the long canzone Ben mi credea passar mio tempo omai (Rvf 207) on c. 90r, Valdezoco sets the type for Rapido fume che d'alpestra vena ( $R v f 208$ ) beginning the sonnet after a full eight blank lines in order to conclude c. $90 \mathrm{r}$ with a complete sonnet:

16. See Gino Belloni's introduction to the 1472 Valdezoco edition (2001, xiii-liv) and his note on the history of Petrarch's partial holograph, MS Vaticano Latino 3195 in Belloni, Brugnolo, Storey and Zamponi 2004, especially 80-93.

17. While all three of these manuscripts demonstrate different page layouts for Petrarch's Rvf, they are linked by the common graphological feature, that is that each manuscript demonstrates a material memory of and link to Petrarch's mise en page for the work. 


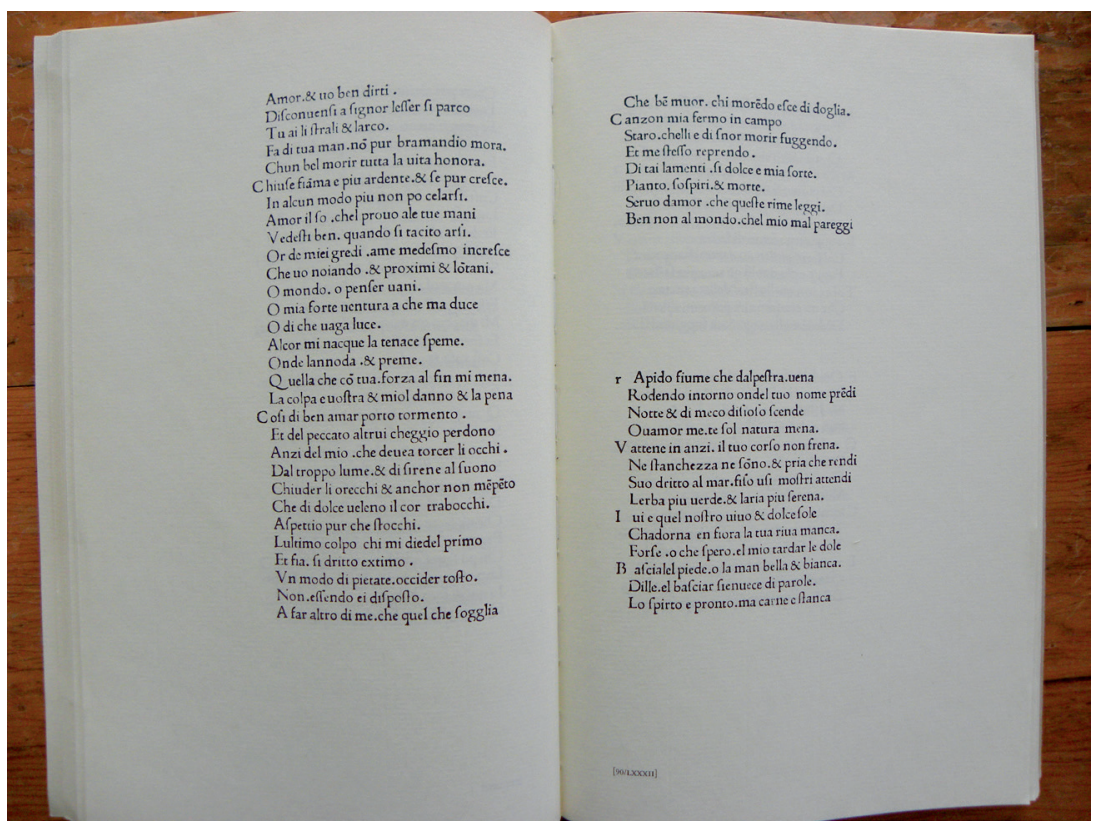

Figure 1. Rerum vulgarium fragmenta, Valdezoco edition 1472, cc. 89v-90r [BELLONI 2001]

With the rediscovery of Petrarch's own final manuscript (Vat. Lat 3195), the editor of the first "critical edition" in 1896, Giovanni Mestica, translates this primacy into a single sonnet per page, fusing the commentary tradition with Valdezoco's editorial principle of 1472.

Even in the 1532 post-mortem and unauthorized printing of Machiavelli's treatise The Prince, we encounter the editorial power of Petrarch's print verses. As the final chapter ends with sixteenth-century print's typically narrowing inverted triangular closure for Machiavelli's prose, Petrarch's verses from his canzone Italia mia (Rvf 128) stand apart and break that closure with their insistent editorial formula of one verse per typographical line.

After decades of talking about textuality, it would probably serve us well to face the fact that modern textual criticism is conditioned and structured by the conventions of print publication, from traditional page layouts that are ironclad not only in their shaping of how we read the text but also how we interpret it.

Indeed since well before Borghini's dilemma until today how we think of and visualize the printed page has configured the norms of our scholarly 
28

9 LIB R $\mathbf{O}$

rstione del'amini, e la uariatione de li ordini. Et guefte fono di quelle cofe, cbe di nuoua ordinate, danno reputatione, $\mathcal{E}$ grande $\vec{a}$ i uno Principe nuouo. Non fi deue adunque lasciare pafsar quefta occa fione, accioche la Italia uegga doppò tanto tempo apparir un' fuo rea dentore. Ne pofso efprimere con quale umore et fujst riceuuto in tutte quelle prouincie, che banno patito per quefte illuutoni efterne, con qual. fete di uindetta, con cbe oftinata fede con cbe pieta, con che lachrime. Q usli porte. fe liferrerebbcno? Quait popoli li negarebbeno la obedien tia ? $Q$ uale inuidia fe liopporrebbe $2 \mathrm{Q}$ uale Italiano li negarebbe

l'os sequio?’à ognun' puza quefto barbaro dominio. Pigli adungue । la Illuftre caja uoftra quefto afsunto con quello animo, o con quelle jperan'é che fi pigliono l'impreje iufte, accio che fotto la fua injegna, er quefta pas= tria ne fia nobilitata, e fotto $i$ fua aufpicyj $f_{i}$ uerifichi quello detto del'Petrarca. Virtì contro al' furore Prenderal'arme, es fia il combatter' corlo, Che l'anticbo ualore.

12. If is Nell Italici cuor? non é ancor morto. U.

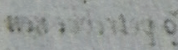

IL FINE DEL PRINCIPE.

Figure 2. Niccolò Machiavelli. 1532. Il principe [. . .], c. 35v. Private collection.

editions from the position of the primary text on the page, the construction of the scholarly apparatus, and the edition's complex system of indexicality down to the print-based notions of accidentals in Greg's method - especially where debates about punctuation are concerned, and, perhaps most curiously, the Lachmannian tendency to disregard print and its 
handwritten marginalia, especially ironic when we consider the fact that one of the oldest copies of the Divine Comedy is to be found in the variants copied by Luca Martini in the margins of a 1515 Aldine edition of Dante. ${ }^{18}$ There is not always a straight line between the influence of the deep structures of print and scholarly editing. But if you pull on the thread of the structure of a critical edition, you'll see how quickly it unravels the fabric of the printed page rather than that of philological methods. This is especially true for the editorial genre of the anthology, from the earliest repertories, such as the 1527 Sonetti e canzoni di diversi antichi autori toscani (Bernardo Giunta), Lodovico Dolce's Primo volume delle rime scelte da diversi autori (Gabriel Giolito 1565), and even Agostino Gobbi's Rime di alcuni illustri autori viventi (Lorenzo Basegio 1727) to the textbooks that still pay more attention to out-of-copyright texts or - perhaps at best the textus receptus of fifty years before and sometimes with only canonical commentary. Usually stripped of their original material and cultural contexts, anthologized poems, often without the benefit of philologically advanced curation, must stand in telegraphically on the printed page for longer, more thoughtful and diversified representations of the richness of literary culture. The role of literary anthologies of every stripe has helped to cement deep cultural and textual accretions in various traditions to the extent that back in 1928 Robert Graves and Laura Riding felt compelled to publish A Pamphlet Against Anthologies to illustrate the editorial excesses of one of literary studies most popular tools.

Clearly the question of print, print traditions and printers and their influence on textual criticism is not a recent one. But we find ourselves in a unique place in the history of communication, not dissimilar to that of Borghini, decades into new digital formulae for representing texts. For if the norms and limitations of print and their effects literally on how we repackage the works we edit are feeling a little threadbare and uncomfortable, it is in part because we are learning more and more about the intervention of consuming cultures on the standards of print, but in part as well because of new, digital ways of thinking, visualizing and reproducing texts. Not since the advent of photography has such an important and yet problematical tool been put into the service of philology, textual editing and the representation of texts.

$$
* * *
$$

18. See Petrocchi 1966, 76-8, for a description of Luca Martini's 1548 collation of the Florentine manuscript of the Commedia transcribed by Forese Donati between October 1330 and January of 1331. Donati's manuscript has been lost for centuries. 
From 1996 until 2003 I was engaged in the preparation of a new diplomatic edition of Petrarch's Rerum vulgarium fragmenta for the Vatican Library's publication of a new, color facsimile of Vatican Latino 3195 and a commentary prepared by three Italian colleagues and myself. Partially in the hand of Petrarch's trusted scribe - we believe to have been Giovanni Malpaghini - under Petrarch's direct supervision, and partially in Petrarch's own hand, both as the hand that intervenes to correct, revise and hone Malpaghini's previous work and as the copyist who completes both Parts I and II and then experiments with final orderings for the last 31 poems, the manuscript is one of the unique jewels in the crown of the Italian literary triad of Dante, Petrarch and Boccaccio. ${ }^{19}$ Off and on I had spent many months of those six years with my head inside the Vatican Library's small wooden light box examining Petrarch's manuscript with a hand-held ultraviolet light, mapping every erasure and mark on the manuscript's 72 chartae, or 144 pages. The manuscript was unbound and then photographed before being rebound in its current red velvet covers. Examining the manuscript in its unbound state, documented in photographs I still turn to, was both an opportunity, for example to study the manuscript's gutters, and a challenge. Like other authors' manuscripts, Vaticano Latino 3195 is a complex "work site". A manuscript that began in 1367 as a fair copy, but eventually turned into the author's working copy, it bears the editorial, poetic and scribal marks left behind by its famous poet-copyist, layer upon layer of erasure, rewritings, sometimes multiple experiments in reordering, and the signs of hands that intervened on the chartae, sometimes even within the text. In the preparation of my own diplomatic-interpretative edition of the work, the more I attempted to represent for print publication what was on the surface (and where possible just below the surface), the more I attempted to represent the manuscript's layers, the more unfit for print my edition became. Many of the editorial devices I was using to portray the manuscript's complexities the more difficult actually reading the texts became for all but the most expert of readers willing to wade through color-coding, diverse fonts, ink saturations and, of course, a paleographic and philological apparatus that could cure any case of insomnia. And my goal had hardly been to produce an edition so complicated that no one would use it to understand better the progression and development of one of the great and influential songbooks of Italian and European literature.

19. For a recent attempt to put into doubt Malpaghini's role as "copyist A", see Berté 2015. Early Italian literature is perhaps unique for its medieval tradition of numerous holographs in the hands of Petrarch and Boccaccio. So far we've found none of Dante's works in his own hand. 
Discussions with the publisher broke down and my diplomatic edition was scrapped in favor of a reprint of Modigliani's 1904 edition.

Annoyed at the time that so much of my work was left on the editorial cutting floor, I can now say it was the best thing that could have happened. My own dilemma over the inappropriate nature of print for my edition, especially after foreseeing what would have been inevitably lost, was by necessity postponed. Even if in $2004 \mathrm{I}$ had wanted to publish my edition online, the digital tools that were ultimately used to create and support the infrastructure of the Petrarchive still hadn't been invented.

At the heart of my own dilemma and skepticism was in truth my own "print thinking": a condition whose methodological contours and implications I had already identified at the beginning of my collaborative work with my friend and colleague at IU, John Walsh, but only fully realized outside the context of my medieval and Renaissance perspectives on print culture when I began reading Marta Werner's chapters for a project devoted to the editing of Emily Dickinson's manuscripts, Dickinson's "Master documents" to be exact. Given Dickinson's idiosyncratic punctuation, line breaks, often coequal authorial variants that occupy virtually the same space on the paper and her works' emphasis on the materiality of their support, it became clear that literary period was not as central to my thinking about notions of visual poetics and the layering of medieval parchment as were the underlying - deeply underlying - structuring conditions of print from its origins to the so-called crisis of scholarly publishing. ${ }^{20}$ For certain authors medieval and modern - and perhaps many more than we imagine when we find their works mostly in "definitive" print editions - but especially those for whom our modern notions of print publication were not central if not anathema to their production, the conventions of print represent a severe reduction of their poetics. Added to Dickinson's textuality are the layers of editorial accretions, or interpretative overlays, that obfuscate her work together with strata of critical and press politics fought over the bodies of editions, making Marta's work directly on the MSS a virtual return to origins absent of print and its conventions. ${ }^{21}$ For authors like Dickinson and Petrarch, two very different characters in world

20. See Dow ling 1997. Among the earliest analyses of the crisis in scholarly publishing in our age was William C. Dowling's 1997 essay, reduced and reprinted in the now defunct but more widely circulated neoconservative The Public Interest. It remains one of the few essays where one can find Aulus Gellius's Noctes Atticae and Erica Rand's Barbie's Queer Accessories cited in the same sentence.

21. Marta Werner's Writing in Time: Emily Dickinson's Master Hours, see Werner 2021. 
literature if ever there were, print has proven to be an editorial straitjacket that chokes off and alters their poetics. The printed text invariably risks representing works as they are interpretatively structured through the lens of a culture's editorial mechanisms, a compromise between the author and the conventions that the reading public seems to expect only because it is what print has taught them to expect.

This is not to say that printed editions are ineffective or nefarious in their textual and interpretative results. Instead it is how we use the printed scholarly edition to impose rules and structures of thought and discourse and to suppress further intellectual invention that is creating in ever greater numbers of scholars, especially younger scholars, a growingly negative reaction to what should be considered the historical richness of print. Rather, what is perhaps needed is a fresh discussion and transparency about and disclosure of the actual, long-term effects of the print tradition on scholarly method and the advancement of our studies of works and their texts.

This kind of renewed focus on the cultural import (and baggage) of print sometimes forgotten by subsequent generations allows us to reevaluate the deep impact that editions of, say, Petrarch's Rerum vulgarium fragmenta or Boccaccio's Decameron have had on the ways we construct our thinking and subsequent representations of those works, both in our acceptance and rejection of previous editorial and interpretative formulations. When we think of the impact even of autograph manuscripts of Petrarch's Rerum vulgarium fragmenta or Boccaccio's Decameron, we must recognize that they are both relatively late scholarly discoveries of the last two centuries and have had to contend with still entrenched critical and editorial accretions accumulated over centuries in previous editions, a kind of textus receptus. ${ }^{22}$

22. Boccaccio's late holograph of the Decameron (Berlin, Staatsbibliothek Hamilton 90), recopied and revised by the author in 1370, just five years before his death, was only recognized in the middle of the twentieth century as being in the author's hand. Petrarch's partial holograph (Vaticano Latino 3195) was proven as belonging to the poet and another trusted copyist only late in the nineteenth century. For Boccaccio, see: CHIARI 1948 and 1955; as well as the confirmation of the manuscript's paternity in BRANCA and RICCI 1962. Chiari reminds us, however, that Boccaccio's hand had already been recognized by no less of a philologist than Michele Barbi who, upon examining the manuscript on-loan to the Biblioteca Laurenziana in Florence in 1933, noted matter-offactly "È lui" (It's him [Boccaccio]). It should be noted that already in 1927 Aldo Massera had published an edition of the Decameron based on Hamilton 90 without claiming its holographic nature, only the quality of its readings. In Petrarch's case, the doubts and battles over the authenticity of the holograph manuscript that 
Added to that, the missing quires in Boccaccio's MS Hamilton 90 have caused methodological questions about the treatment of the text in critical editions that resort to solutions that rely solely on Mannelli's old 1384 "ottimo esemplare" that we saw earlier. And in spite of Petrarch's highly nuanced visual poetics, a virtual road map to how he wanted his poems to appear both in relation to one another and as a songbook, old print standards that date back to the fifteenth century still guide editors of printed books. ${ }^{23}$

These days, publishing houses and philology find themselves on hard times. Most of my friends and fellow philologists turn to fewer and fewer venues to publish print editions with dramatically reduced philological flexibility and small print-runs that require subventions from institutions that seem ever less willing to invest in the humanities if they are not "digital". What does get published is subject to ever-stricter print values. And printing itself seems to have forgotten many of the skills of its glorious past. Complex foldouts were once a main stay of scholarly printing, and not just for technical publications, from Alessandro Vellutello's 1525 foldout map of Vaucluse to Avignon to the foldout of the family tree of Francesco d'Amaretto, the copyist of the "Ottimo Testo" of the Decameron printed in 1761 .

And those familiar with Abraham Nicolas Amelot de la Houssaye's Histoire du Gouvernement de Venise, for which the author-diplomat spent some weeks in the Bastille, cannot imagine the work without the third edition's integral foldout illustrations that demonstrate the central places and hierarchies of the Venetian state in the late seventeenth century.

But rather than building on such a wondrous feature, modern presses invariably refuse such "innovations" as the foldout by claiming it would make the book's production costs too high and leading us right back to the Giunti's 1573 critique of printers.

would become Vaticano Latino 3195 started with Pietro Bembo's interest in the codex first as a late source for his 1501 Aldine edition (registered in his own editor's copy, now MS Vaticano Latino 3197) and again later as a personal acquisition (Вемво 1552, II: 303) for his library before the manuscript passed through the hands of Fulvio Orsini and into the Vatican Library, where it sat virtually unnoticed until 1886 when both Pierre De Nolhac $(1886,1887)$ and Arthur PAKscher (1886) claimed the manuscript to be partially in Petrarch's hand.

23. See Storey 1993, 201-433 for a general introduction to Petrarch's visual poetics with examples; Storey 2004 for the principles of punctuation, space and markers in Petrarch's holograph; and Storey 2011 for an introduction to the early reception of Petrarch's poetic layouts in manuscript and print. 


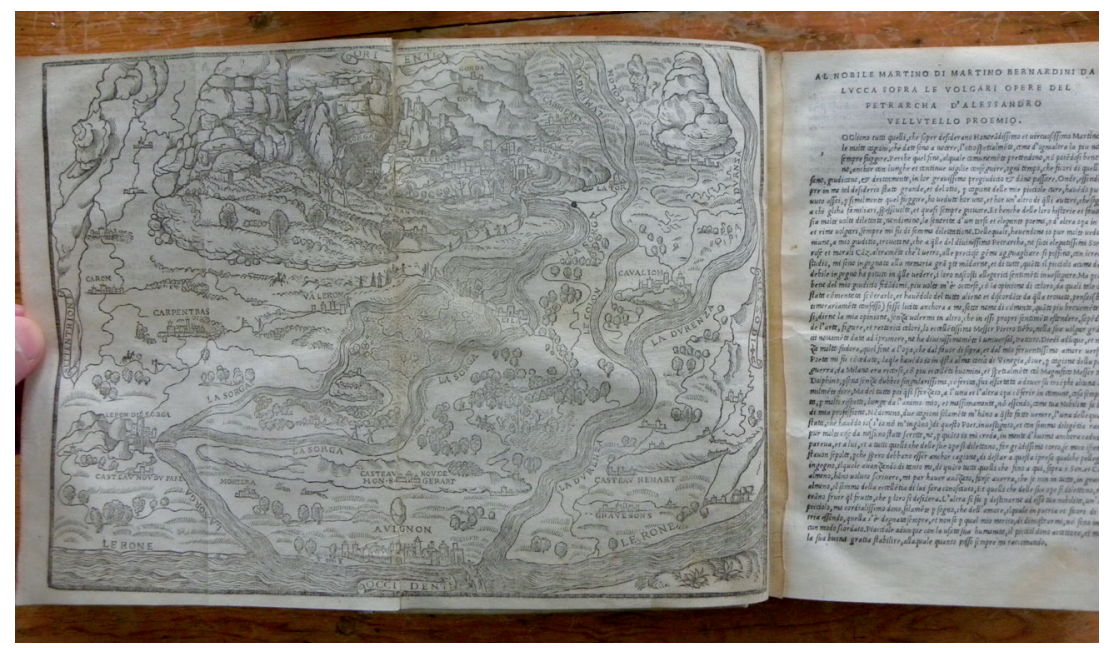

Figure 3. Alessandro Vellutello, ed. 1525. Le volgari opere del Petrarcha con la espositione di Alessandro Vellutello da Lucca. Venezia: Giovanniantonio \& Fratelli da Sabbio, sign. Aa4v. Private Collection.

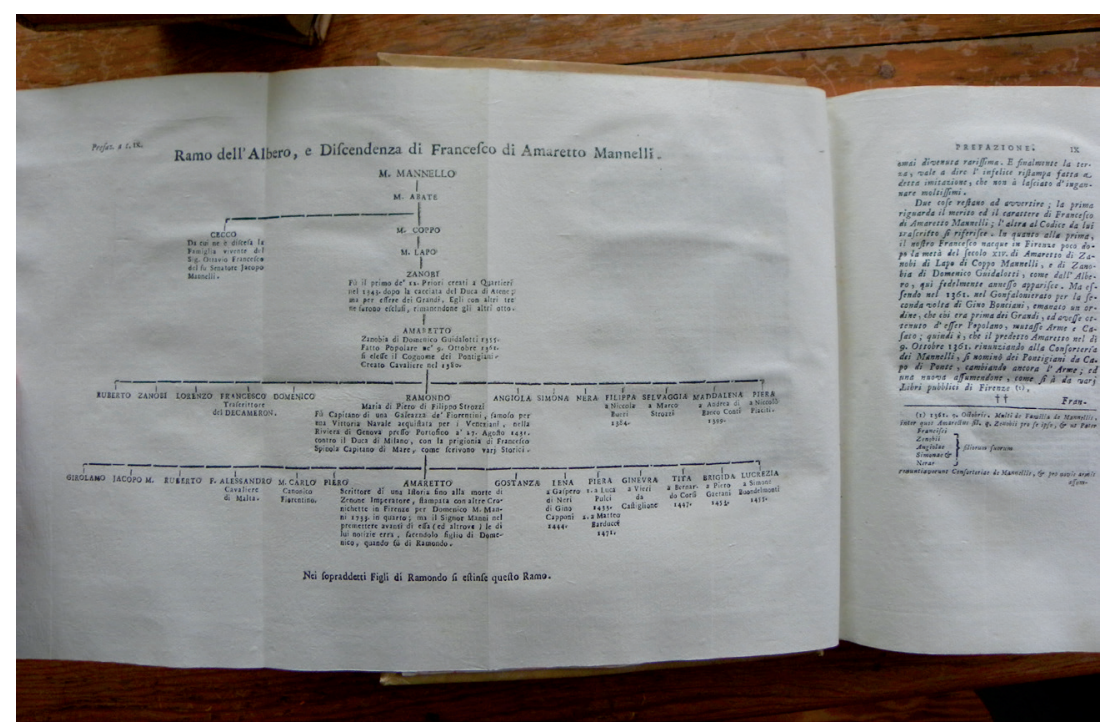

Figure 4. 1761. Il Decameron di M. Gio[vanni] Boccaccio tratto dall'Ottimo Testo scritto da Fran[ces]co d'Amaretto Mannelli sull'Originale dell'Autore, infra VIII et IX. Private Collection. 


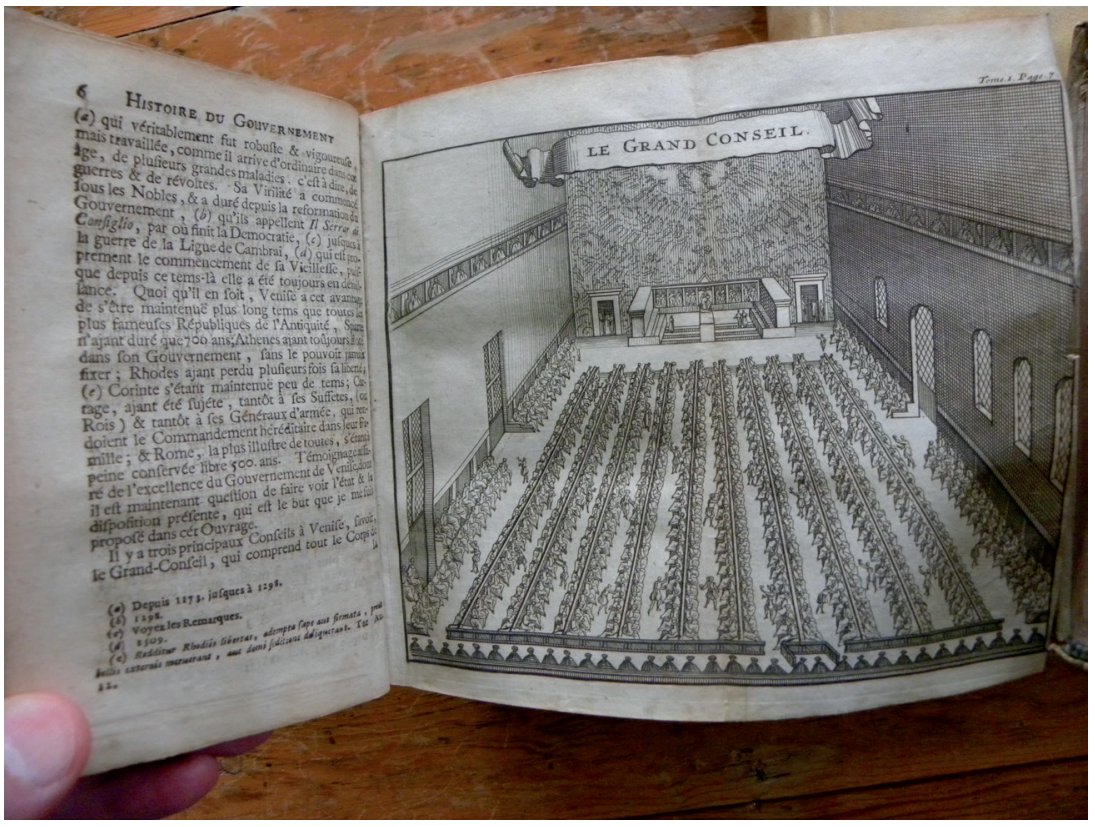

Figure 5. Amelot de la Houssaie, [Abraham Nicolas]. 1705. Histoire du Gouvernement de Venise. Tome Premier. Amsterdam: Pierre Mortier, pag. infra 200 et 201 (Veue de la Place St. Marc). Private Collection.

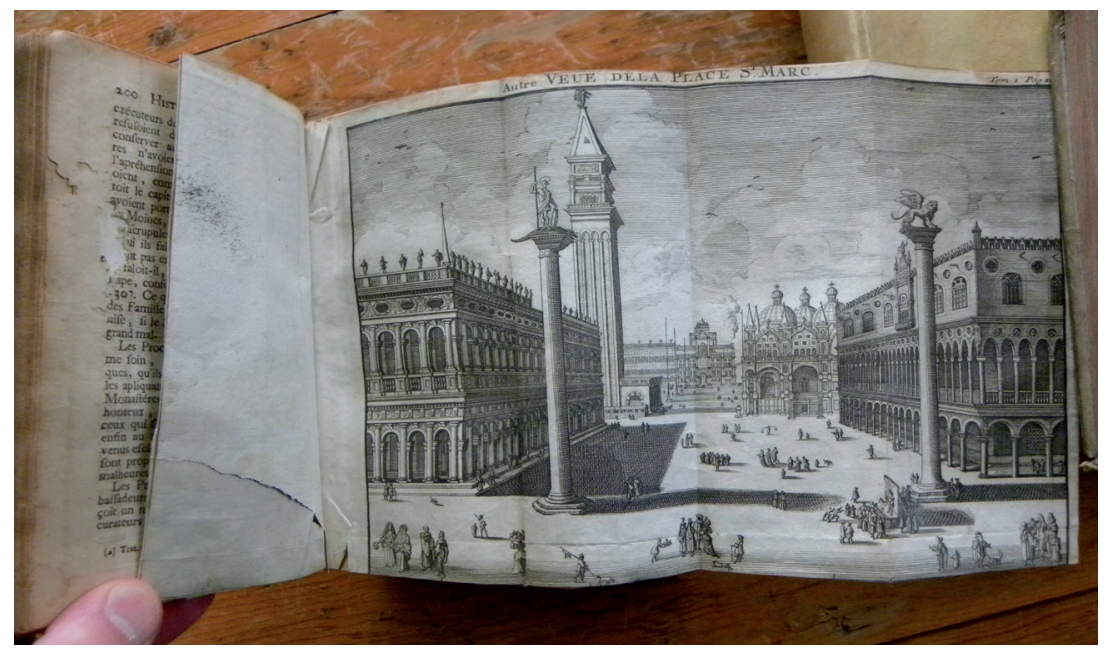

Figure 6. Amelot de la Houssaie, [Abraham Nicolas]. 1705. Histoire du Gouvernement de Venise. Tome Premier. Amsterdam: Pierre Mortier, pag. infra 6 et 7 (Le Grand Conseil). Private Collection. 
Materially, intellectually and culturally we are at a crossroad, and I'm telling you nothing new when I say it's a bit like a war zone, alas in a war we've been in for a good twenty-five years. When, after early discussions with my future collaborator John Walsh, I first began learning the ins and outs of the digital publication of texts, I did so with trepidation. The world of online publication was and still is to a great extent the Wild West of publication. Many of us quickly grew tired of texts scanned with Optical Character Recognition (or OCR) and thrown up on the Web as "online editions". The problem still lurks, however, often in the form of "big data" results, where thousands of OCR scanned texts, produced with early and flawed recognition software, are analyzed to tell us about "Culture". Even the very expensive 2004 facsimile edition of Petrarch's Rerum vulgarium fragmenta that boasts of very high-resolution photographs of Petrarch's manuscript includes a packet of virtually restored images of some chartae where faded ink and other material damage has been digitally "corrected", but often with unfortunate results (see Storey 2004, 135n13).

Like their counterparts in print, serious digital editions of texts are crafted with painstaking work that is intellectual, conceptual and very much the product of digital tools that must be sustainable over time. Serious digital editions take a long time and many collaborative and diversified hands to make: a fact not reflected in universities' often-unrealistic enthusiasm for "the Digital Humanities". One exercise I liked to conduct with my graduate students was the construction of a small, experimental site with an edition and critical apparatus for a single sonnet. One quickly learns that the sparkle of a well-crafted, digital edition, even of a single 14-verse poem, is not so easy to accomplish. Rather - as many of you know - a sound, functioning site/archive with a digital edition takes years of planning, conceptualization, encoding (or rewriting the texts in a new "tag language"), revision and integration of the codes, and finally a lot of testing, checking for broken code, and frequent maintenance. Thanks to many truly fruitful collaborations throughout the scholarly world we have made important advances in the viability and stability of digital editions and archives. Yet I would quickly add that we still have not tamed the Wild West. In spite of initiatives such as the Modern Language Association's 2016 "Statement on the Scholarly Edition in the Digital Age" (see Modern Language Association 2016) and Michelangelo Zaccarello's proposed 2017 "Committee on Digital Oversight for Italian Editions" (Osservatorio permanente sulle Edizioni Digitali di Autori Italiani [ OPEDAI ]) and a growing number of evaluative resources for digital sites, we are still far from any kind of standardized formulae for the digital publication of works and documents. 
This is a good thing. Efforts, especially institutional efforts, to impose standardized forms and operating systems would choke innovation in numerous sectors, including the philological. In the last few years, academic-political turf wars undertaken by some institutions in surprisingly central fields of inquiry have suppressed or significantly altered initiatives that simply became bogged down in issues of public access, limited rights, firewalls, philological sources, and even page design.

In the case of the Petrarchive (http://petrarchive.org), John Walsh, Isabella Magni and I, along with many helping hands and consulting specialists have kept well under the radar of institutional intervention. And to their credit, Indiana University and the National Endowment for the Humanities have been truly benevolent and generous hosts and supporters. Our first two years of existence (2013-2014) were spent purely talking through and mapping structures and infrastructures and creating prototypes of diverse forms of representation of Petrarch's manuscripts and poems. In 2013 I had already been working on my own new edition, along with additional studies for a diplomatic edition, of Petrarch's Rerum vulgarium fragmenta and its early manuscripts, especially Petrarch's autograph copy, for some 22 years. Yet the weekly meetings with our small team of web designers, philologists and encoders to discuss everything from how to present sestinas that would be faithful to Petrarch's visual poetics to the code for complex forms of blank space as micro- and macrotextual punctuation in medieval manuscripts quickly taught me to rethink the results of my years of research in Petrarch's texts in new, philological ways, especially when it came to their representation. I had long been convinced of the necessity of representing the texts of the Rerum vulgarium fragmenta in the visual-poetic poetic form that Petrarch gave them rather than in the forms into which often anonymous, fifteenth-century scribes and typesetters had transformed them, the very transformed layouts in which modern print editions still incorrectly cast one of the most influential songbooks of Western literature. But old problems of representation lingered; and these were some of the first "hard cases" we elected to tackle in our early discussions and prototypes. One of the hardest was also one for which Petrarch himself had to find a makeshift material solution: a poem that wouldn't fit and couldn't be credibly handled by his usual solution of adding a bifolium (a folded sheet to make two chartae, or four pages front and back, as he did at the ends of Part I (Vaticano Latino 3195, cc. 49-52) and II (cc. 61-72 in the form of three separate bifolia [Fascicles X and XI folded into Fascicle IX]): 

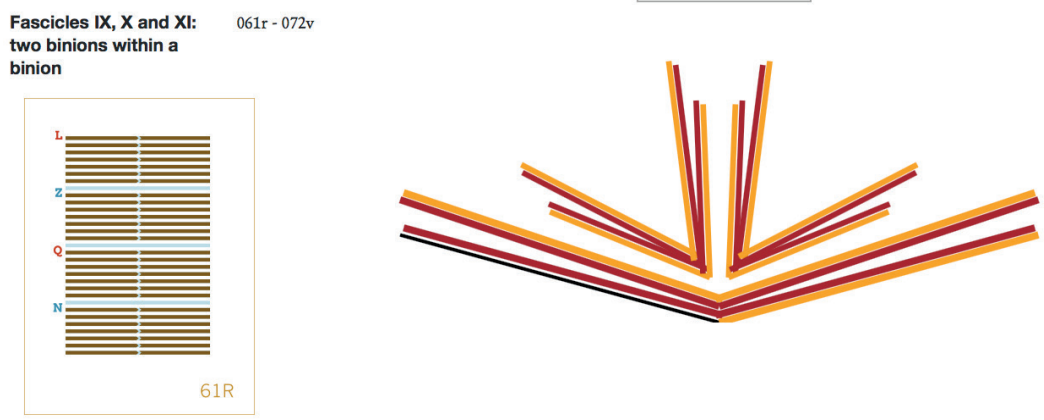

Figure 7. Fascicles IX, X, and XI (respectively cc. 61-62|71-72, 63-66, and 67-70 of Vaticano Latino 3195. From the Fascicler of the Petrarchive: http://petrarchive.org

In Fascicle XI, Petrarch faces the prospect of copying the long canzone Quel' antiquo mio dolce empio signore (Rvf 356 [revised as 360]) onto two sides of two chartae, $69 \mathrm{v}$ and 70r. But the canzone's 157 verses, which Petrarch would normally have copied in the same layout as the poem's prosodic sister, Una donna più bella assai che 'l sole (Rvf 119), simply won't fit in the space he has. Following his mise en page model he would have to do the materially impossible, add a single charta. Instead he copies the poem's stanzas 15 verses three verses per transcriptional line on five lines in a kind of medieval zip-form that would be expanded in a fair copy. By now the manuscript is little more than a draft or service copy which, according to Petrarch's habit, would have been destined to be rewritten as a fair copy by a professional scribe. As we see in the click that takes us from the diplomatic to the edited version, the digital edition automatically expands the canzone into the form it takes in later manuscripts such as New York Morgan Library M502 and Firenze, Biblioteca Laurenziana Segniano 1:

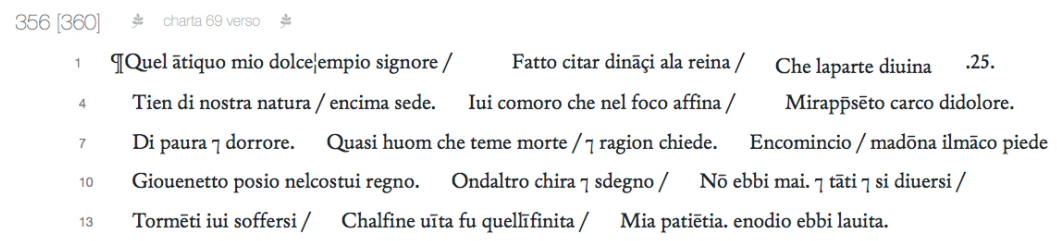

Figure 8. Quel' antiquo mio dolce empio signore, Rvf 356[revised as 360], vv. 1-15. From the Petrarchive: http://petrarchive.org; diplomatic form. 


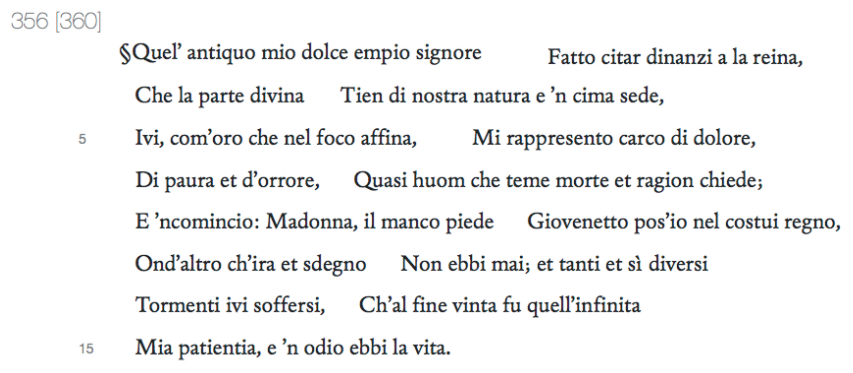

Figure 9. Quel' antiquo mio dolce empio signore; Rvf 356[revised as 360], vv. 1-15. From the Petrarchive: http://petrarchive.org; edited and expanded version.

This expansion of Petrarch's "zip file", of course, raises other representational questions as we move outside the material limits of his manuscript Vaticano Latino 3195 to "virtual chartae" to reconstruct the poem's ideal, edited form. It is an act of digital interpretation based on our best philological information about Petrarch's own transcriptional matrices and systems. It is also an act that interprets the very nature of Petrarch's manuscript at this stage of its execution, that is a draft/service copy.

In all honesty, for me these first years of our Petrarchive collaboration were spent in good part teaching myself to move from print thinking to a digital re-envisaging the complex details of Petrarch's macrotext. Nowhere was this truer than our discussions and my own thinking about what to do with a "textual component" that you will find only in one other edition: the blank chartae, to be precise - seven (six ruled) blank sides of four chartae (or seven pages) that Petrarch leaves between the two parts of the Fragmenta (Part I: Rvf 1- 263, cc. 1r-49r; and Part II: Rvf 264-366, cc. $53 \mathrm{r}-72 \mathrm{v}) .{ }^{24}$ In the play between its regularity and its alteration, blank space has an especially important diacritical role in manuscripts that we can recuperate in the digital. Modigliani only partially accomplishes this in his diplomatic edition. Key to our interpretative encoding of these pages as

24. The only edition in which these "blank pages" is Modigliani's diplomatic edition (Modigliani 1904, 114-20 (or cc. 49v-52v), though for c. 49v, which appears today to be blank, the otherwise cautious Modigliani must face the other problem of print: representing erasures that can still be read, which he does by including a more recent colophon and two long notes to explain its presence. Modigliani fills half the otherwise blank page of his diplomatic edition with text that one can't see with the naked eye, but does not represent the pages' rulings, a usually key preparation before the parchment was used. 
"potential textual space" was also our underlying decision to represent the division of the textual space by the 31 ruled lines of Petrarch's very regular transcriptional "canvas".

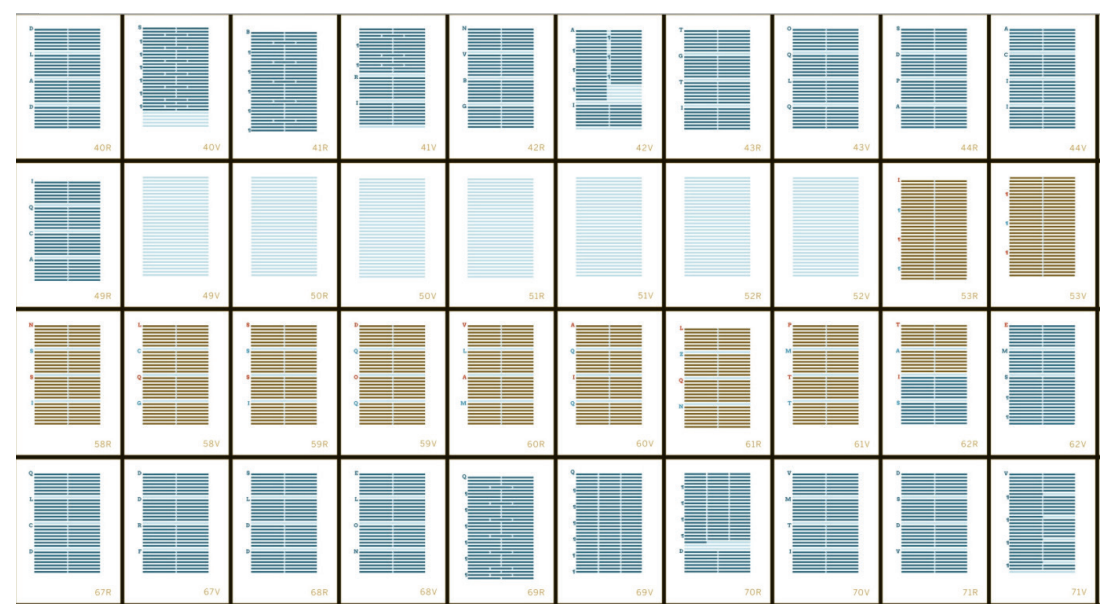

Figure 10. Detail of the Visual Index of the Petrarchive: http://petrarchive.org; Line graphs for selected chartae.

Following the typical medieval practice of leave a blank charta as a textual divider between significant sections of a work, or between works themselves, Petrarch could easily have intended c. $52 \mathrm{v}$ as just such a divider between Parts I and II. But what would have been the reason for leaving so many ruled chartae blank (49r-52r)? Especially the entirely empty bifolium (cc. 50-51) at the heart of the binion (cc. 49-52)?
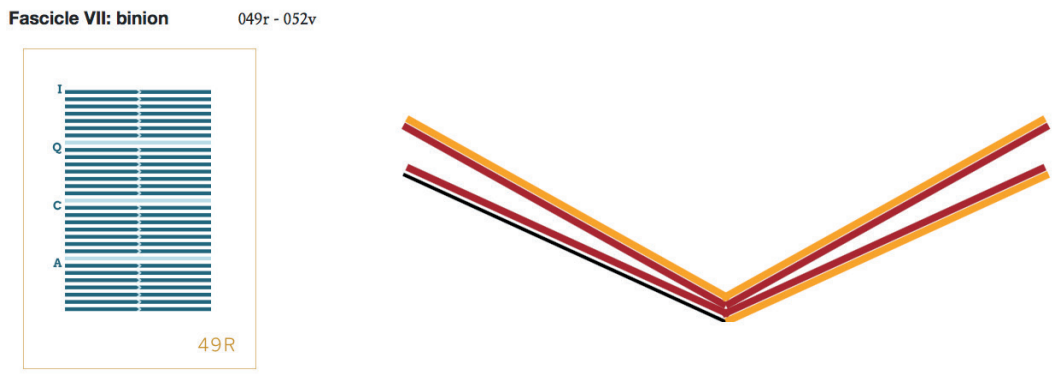

Figure 11. Fascicle VII Binion, Vaticano Latino 3195, cc. 49-52; Fascicler of the Petrarchive: http://petrarchive.org. 
Our explicit coding of the 'function' of the seven blank pages as 'potential poetic space' has raised questions. Why represent blankness? Petrarch himself was responsible for preparing the two bifolia of the binion, Fascicle VII (today chartae 49-52) to transcribe the last four sonnets (Rvf 260263; from In tale stella to Arbor victoriosa) he inserted into Part 1. While Petrarch uses only the recto of c. 49, all four chartae have been ruled in dry point with 31 lines, his usual canvas. The internal bifolium, cc. 50-51, was simply a folded and ruled sheet that was never used. Did he intend to use the final three chartae of Fascicle VII to record additional poems? Numerologist Petrarch scholars will tell you No; he could not have intended to add to his perfect "calendar" of 366 poems. The material evidence tells us only that the extra chartae were ruled and kept by the poet among his drafts at the time of his death in 1374 . They were subsequently bound into the manuscript that Pietro Bembo later described as having seen briefly and that it was bound in white leather. ${ }^{25}$

But there is an additional, scholarly reason for identifying and encoding those blank chartae. It begins to answer an historical question about the view and treatment of authenticity and the justification of textual editing in antiquity, or at least in the fourteenth to the sixteenth century. After Petrarch's death in 1374, the race to establish the "true" text of Petrarch's Rerum vulgarium fragmenta was often founded on claims of access to the poet's "original". This was certainly Aldo Manuzio's claim to the readers of his 1501 edition of Petrarch's Cose volgari. But already in the late fourteenth and the fifteenth centuries, copyists had begun to identify variants as coming directly from the "hand of the poet" (even as late as in the collated seventeenth-century MS Casanatense 924). In several cases, these claims of authenticity and the use of the poet's own personal copy point specifically to a manuscript that had four empty chartae between Parts 1 and 2. One of these witnesses, MS M706 at the Beinecke Library at Yale, records the rubric between Parts I and II: "Que sequuntur post mortem domine Lauree scripta sunt [. . .] proprio codice domini francisci annota-

25. See Вемво 1552, II: 302-4, both letters to Girolamo Quirini (23 August and 20 September 1544), in which Bembo first queries Quirini if the book that Quirini has located is the one in "worn white leather" that Bembo had seen many years before in Padova and was now trying to acquire. In the second, of 20 September, Bembo declares to Quirini that the manuscript is precisely the one and: "È di mano dell'autor suo senza nessun dubbio" (It is without a doubt in the hand of its author [303]). 
tum est et carte quatuor pretermisse vacue". ${ }^{26}$ While not part of Petrarch's text, the rubric of this 1393 Veronese exemplar, dutifully copied by the late fifteenth-century scribe of Beinecke M706, directly links both the early dissemination and the 1393 copy's claims to editorial accuracy to a material feature, those four blank chartae, that was in the last quarter of the fourteenth century ascribable to Petrarch's own hand. The digital representation of the blank pages, accompanied by an apparatus that examines its editorial treatment in diverse historical contexts, maintains a key material feature of the structure of Petrarch's own artifact and documents its role in the structure of the macrotext.

To this day if you ask me if something called "Digital Philology" exists, my first inclination would probably be to say no. But when I reflect on the transformation of my own thinking in these years of collaborating on the Petrarchive and all I've learned about textuality by having to represent it in digital forms that are more reflective of Petrarch's linguistic, formal and material structures, then I would have to say yes, absolutely. Digital Philology is a vehicle born out of the strictures of philology too often chained to print, a philological exploration that requires new ways of thinking and new tool sets to reconstruct literary works and their texts in more authentic contexts. We are at the nexus between Material and Digital Philology. The digital gets us closer to more accurate visualizations not just of texts and their reconstructions but of the more human and layered dimensions present in the construction of manuscripts and the texts they contain.

I would like to tell you that digital editions are the solution to the unhappiness in which philologists and textual scholars currently find themselves. While I believe they are a robust scholarly tool in the advancement of philology, editions and serious textual studies, I fear they will not improve your happiness. Like all serious endeavors there are no quick fixes that actually fix and promote the "textual condition". We have seen the results of easy digital works that rely on other editions that have been scanned and "made available" to readers. Aside from the errors owed to OCR, they are better considered sites devoted to the history of reception. But scholarly digital projects big and small can take many years to plan, complete and maintain. During those years the tasks of checking for digital errors in the code and interface (and thus in what you see on the screen) seem never-ending, especially when the team is small. But the challenge to rethink what we

26. These [poems] that follow are written about Madonna Laura after her death [. . .] from a manuscript that has been annotated by Master Francesco, and he placed between [the two parts] four blank chartae [or leaves]. 
thought we knew and to move our thinking away from print and toward more deeply layered forms of textual representation can only sharpen our philological skills while, one hopes, making us and the ways we communicate philological concepts and results less insular and more central to cultural discussions in which we should be involved.

Somewhere between the continual improvement and growing rigor of the digital and the discouragement of a faltering book trade, philologists of every kind (traditional, material, digital) will hopefully take up our tools and make our standards even more rigorous. In the choice between studying and preserving our cultural heritages or allowing them to sink under the weight of obstinate resistance to technology, I hope that cultural heritage wins out, whatever representational form that victory will ultimately take. Just as Vincenzo Borghini, troubled I believe at numerous levels by his task, acted to save what he could of Boccaccio's literary icon, we must gather our skills and act. And just taking the books we are writing for print publication and creating e-books with page-turner does not a revolution in textual studies make. To be good digital philologists that revolution must begin in our heads and how we think, not in the repurposing of our products.

The Society for Textual Scholarship must itself be an actor in this task. The evolution of a society (lest we forget once a renegade society) originally organized to investigate and support diverse views in editorial theory and practice has a vital role to play; not to become another digital conference with sessions devoted solely to new tools and improvements in TEI. There are plenty of venues for that kind of important research. Rather I would suggest that now more than ever the Society can strengthen its voice as a cooperative, expert collaborator in the rigors of editing and textual preparation for digital editions. Those of you who have taken up the hard work of collaborating on a digital edition or archive know that artful balance of rigor and intellectual flexibility can make us weary, but we cannot abandon our posts, or our scholarly curiosity, or our principles, just re-examine them from time to time.

Deep River, Connecticut

\section{Works Cited}

Belloni, Gino, ed. 2001. Francesco Petrarca. Rerum vulgarium fragmenta. Anastatica dell'edizione Valdezoco Padova 1472. Venezia: Regione del Veneto - Marsilio.

Belloni, Gino and Riccardo Drusi. 2002. Vincenzio Borghini. Filologia e invenzione nella Firenze di Cosimo I. Firenze: Olschki. 
Belloni, Gino. 2004. “Nota sulla storia del Vat. Lat. 3195”. In Belloni, Brugnolo, Storey, and Zamponi 2004, 73-104.

Belloni, Gino, Furio Brugnolo, H. Wayne Storey, and Stefano Zamponi. 2004. Rerum vulgarium fragmenta. Codice Vat. Lat. 3195. Commentario all'edizione in facsimile, Roma-Padova: Antenore.

Bem во, Pietro. 1552. Delle lettere di Pietro Bembo. Vol. 1-4, seconda impressione. Venezia: Gualtero Scotto.

Berté, Monica. 2015. "Giovanni Malpaghini copista di Petrarca?" Cultura Neolatina 75.1-2: 205-16.

Borghini, Vincenzo, ed. 1573. Il Decameron di messer Giovanni Boccacci cittadino fiorentino. Ricorretto in Roma, et emendato secondo l'ordine del Sacro Conc[ilio] di Trento, et riscontrato in Firenze con Testi Antichi $\mathcal{E}$ alla sua vera lezione ridotto da' Deputati di loro Alt[ezze] Ser[enissime]. Firenze: Giunti.

- 1574. Annotationi et discorsi sopra alcuni luoghi del Decameron di M. Giovanni Boccaci; Fatte dalli molto Magnifici Sig. Deputati da loro Altezze Serenissime, sopra la correttione di esso Boccaccio, stampato l'anno MDLXXIII. Firenze: Giunti.

BrancA, Vittore, and Pier Giorgio Ricci. 1962. Un autografo del Decameron (Codice Hamilton 90). Firenze: Olschki.

ed. 1992. Giovanni Boccaccio, Decameron. 2 vols. Torino: Einaudi.

Chiari, Alberto. 1948. "Un autografo del Decameron? La Fiera letteraria 11 luglio, 27. 1955. "Ancora sull'autografia del codice berlinese del Decameron". Convivium n.s. 23: 352-6.

Conway, Melissa. 1999. The Diario of the Printing Press of San Jacopo di Ripoli 14761484. Firenze: Olschki.

Cursi, Marco. 2007. Il Decameron: scritture, scriventi, lettori. Storia di un testo. Roma: Viella.

De Nolhac, Pierre. 1886. Le Canzoniere autographe de Petrarque. Communication faite à l'Académie des Inscriptions et Belles-Lettres. Paris: Klincksieck. 1887. La Bibliothèque de Fulvio Orsini. Paris: E. Buillon and E. Vieweg.

Dowling, William C. 1997. "Saving Scholarly Publishing in the Age of Oprah. The Glastonbury Project". Journal of Scholarly Publishing 28.3 (April); partial rpt. as "The Crisis of Scholarly Publishing", in The Public Interest 129 (Fall): 23-37.

Fanfani, Pietro, ed. 1857. Annotazioni et discorsi sopra alcuni luoghi del Decameron di M. Giovanni Boccaci; Fatte dai Deputati alla correttione del medesimo, 4th ed. Firenze: Le Monnier.

Machi avelli, Niccolò. 1532. Il principe di Niccholo Machiavello al Magnifico Lorenzo di Piero de Medici, cc. 2r-35v. Roma: Antonio Blado d'Asola.

Magni, Isabella, H. Wayne Storey and John Walsh. 2014-2020. The Petrarchive: a Rich-Text Digital Edition and Commentary of Petrarch's Rerum vulgarium fragmenta. http://petrarchive.org.

Modern Language Association. 2016. "MLA Statement of the Scholarly Edition in the Digital Age", prepared by the Committee on Scholarly Editions (2015). https://www.mla.org/content/download/52050/1810116/rptCSE16.pdf 
Modigliani, Ettore, ed. 1904. Francisci Petrarche Laureati Poete Rerum vulgarium fragmenta. Roma: Società Filologica Romana.

PAKscher, Arthur. 1886. "Aus einem Katalog des Fulvius Ursinus". Zeitschrift für romanische Philologie 10:205-45.

Petrocchi, Giorgio, ed. 1966. Introduzione, vol. 1 of Dante Alighieri. La Commedia secondo l'antica vulgata. Milano: Mondadori.

Storey, H. Wayne. 1982. 'Parodic Structures in 'Alibech and Rustico': Antecedents and Traditions". The Canadian Journal of Italian Studies 5: 163-76.

1993. Transcription and Visual Poetics in the Early Italian Lyric. New York London: Garland.

. 2004. "All'interno della poetica grafico-visiva di Petrarca". In Belloni, Brugnolo, Storey and Zamponi 2004, 131-71.

- 2011. "Petrarch's 'Original' of the Fragmenta 1362-1558. From Boccaccio to Rovillio's Third Printing”. Humanist Studies $\mathcal{E}$ the Digital Age 1.1 (Winter): 28-49.

Vellutello, Alessandro, ed. 1525. Le volgari opere del Petrarcha con la espositione di Alessandro Vellutello. Venezia: Giovanniantonio \& Fratelli da Sabbio.

Werner, Marta. 2021. Writing in Time: Emily Dickinson's Master Hours. Forthcoming. Amherst: Amherst College Press. 